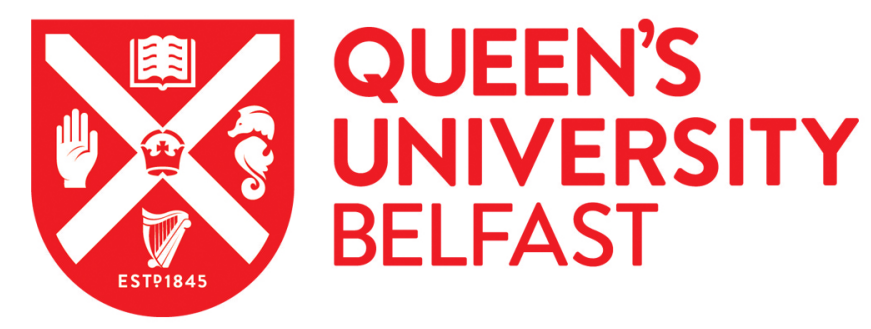

\title{
Young, Old, and Weathered Carbon-Part 2: Using Radiocarbon and Stable Isotopes to Identify Terrestrial Carbon Support of the Food Web in an Alkaline, Humic Lake
}

Keaveney, E. M., Reimer, P. J., \& Foy, R. H. (2015). Young, Old, and Weathered Carbon-Part 2: Using Radiocarbon and Stable Isotopes to Identify Terrestrial Carbon Support of the Food Web in an Alkaline, Humic Lake. Radiocarbon Journal, 57(3), 425-438. https://doi.org/10.2458/azu_rc.57.18355

Published in:

Radiocarbon Journal

Document Version:

Peer reviewed version

Queen's University Belfast - Research Portal:

Link to publication record in Queen's University Belfast Research Portal

Publisher rights

Copyright 2015 The Authors

\section{General rights}

Copyright for the publications made accessible via the Queen's University Belfast Research Portal is retained by the author(s) and / or other copyright owners and it is a condition of accessing these publications that users recognise and abide by the legal requirements associated with these rights.

\section{Take down policy}

The Research Portal is Queen's institutional repository that provides access to Queen's research output. Every effort has been made to ensure that content in the Research Portal does not infringe any person's rights, or applicable UK laws. If you discover content in the

Research Portal that you believe breaches copyright or violates any law, please contact openaccess@qub.ac.uk. 


\section{Young, old and weathered carbon (2): using radiocarbon and stable isotopes to identify terrestrial carbon support of the food web in an alkaline}

\section{humic lake:}

Evelyn Keaveney ${ }^{1}$, Paula J. Reimer ${ }^{1}$, Robert H. Foy ${ }^{1,2}$

${ }^{114}$ CHRONO Centre, School of Geography, Archaeology and Palaeoecology, Queen's University Belfast, BT71NN

${ }^{2}$ Agri-Food and Biosciences Institute, Newforge Lane, Belfast, BT95PX

\section{ABSTRACT}

Carbon $(\mathrm{C})$ and nitrogen $(\mathrm{N})$ stable isotope analysis (SIA) has been used to identify the terrestrial subsidy of freshwater food webs. However, SIA fails to differentiate between the contributions of old and recently fixed terrestrial $\mathrm{C}$ and consequently cannot fully determine the source, age and biochemical quality of terrestrial carbon. Natural abundance radiocarbon $\left(\Delta^{14} \mathrm{C}\right)$ was used to examine the age and origin of carbon in Lower Lough Erne, Northern Ireland. Radiocarbon and stable isotope values were obtained from invertebrate, algae and fish samples and the results indicate that terrestrial organic $\mathrm{C}$ is evident at all trophic levels. High winter $\delta^{15} \mathrm{~N}$ values in calanoid zooplankton $\left(\delta^{15} \mathrm{~N}=24 \%\right.$ ) relative to phytoplankton and $\operatorname{POM}\left(\delta^{15} \mathrm{~N}=6 \%\right.$ and $12 \%$ respectively $)$ may reflect several microbial trophic levels between terrestrial $\mathrm{C}$ and calanoid invertebrates. Winter and summer calanoid $\Delta^{14} \mathrm{C}$ values show a seasonal switch between autochthonous and terrestrial carbon sources. Fish $\Delta^{14} \mathrm{C}$ values indicate terrestrial support at the highest trophic levels in littoral and pelagic food webs. Radiocarbon therefore has utility in attributing the source of carbon in freshwater in addition to tracing the pathway of terrestrial carbon through the food web.

Keywords: Lake. Food web. Radiocarbon. Stable isotope. Fish. 


\section{INTRODUCTION}

The investigation of trophic levels in a food web is complex yet fundamental when understanding the dynamics of a freshwater system. Identification of carbon sources can be problematic due to large variation of stable carbon isotope values in freshwater systems, and becomes even more difficult when there is a significant terrestrial subsidy of the food web as terrestrial and freshwater isotope values often overlap. C inputs to lakes can represent a significant component of the diet of lake heterotrophs (organisms unable to synthesise their own organic carbon).

Organic carbon utilised in aquatic food webs is derived from both autochthonous (derived from primary production within the system) and allochthonous (terrestrial) carbon imported from the catchment. Studies showing the influence of terrestrial carbon on food web dynamics have largely dealt with non-eutrophic lakes which are predominantly supported by terrestrial carbon (ÅGren et al. 2008; Gratton et al. 2008; Seifert and Scheu 2012; Lapierre et al. 2013; Wilkinson et al. 2013b; Wilkinson et al. 2013a). However, lakes with higher trophic status may also be supported by catchment inputs; the terrestrial support of pelagic food webs in such lakes is difficult to ascertain and can be underestimated.

Seasonal changes in productivity affect the delivery of nutrients (Grey 2001; Kritzberg et al. 2006b; Neff et al. 2006; Rautio et al. 2011). Terrestrial carbon can supplant autochthonous carbon in systems with low algal abundance. The availability of this carbon to lake heterotrophs (organisms that cannot fix carbon but utilise organic carbon for growth) is related to its age, which in turn is related to its biochemical composition and nutrient quality (biochemical quality). Bacteria have been shown to metabolise both autochthonous carbon and labile and decayed terrestrial carbon (Guillemette et al. 2013) but preference is linked to nutrient content which decreases over time leading to preferential selection of autochthonous 
and labile terrestrial carbon sources (Taipale et al. 2007; McCallister and Giorgio 2008;

Taipale et al. 2008; de Kluijver et al. 2012; Zigah et al. 2012).

\section{Freshwater Carbon sources}

Carbon derived from primary production is bio-energetically rich compared to terrestrial input to lakes, particularly previously sequestered detrital carbon which has undergone diagenesis in soil or peat. As carbon sources fluctuate seasonally, heterotrophic organisms can switch between autochthonous or allochthonous sources to exploit high quality carbon sources (Maguire and Grey 2006; Rautio and F Vincent 2007; Taipale et al. 2008; Rautio et al. 2011).

Terrestrial organic matter has been shown to enter aquatic food webs in a number of ways. Terrestrial dissolved organic carbon (DOC) can be utilised by mixotrophic (utilising a mixture of autotrophic and heterotrophic modes) and heterotrophic bacteria (Tittel et al. 2009; Cole et al. 2011; Rottberger et al. 2013). Particulate organic matter (POM) of terrestrial origin often forms important foci for bacterial production. Subsequent consumption of bacteria can also be an important pathway into food webs (Kritzberg et al. 2006a; Cole et al. 2011).

\section{Stable Isotope Analysis of food webs}

Food web utilisation of terrestrial organic subsidies in lakes has been demonstrated for many widely distributed global locations, and for the most part these involve the use of natural abundance or artificially enriched stable isotopes of carbon and nitrogen (Perga and Gerdeaux 2004; Carpenter et al. 2005; Kritzberg et al. 2006a; Marty 2007; Taipale et al. 2008).

Detecting the source of carbon can be problematic however when using SIA. Kinetic stable isotope fractionation leads to differences in pelagic (open water) and littoral (near shore) areas of the lake, and between organisms and their dietary sources (Fry 1991). It is difficult to 
physically isolate phytoplankton samples and to accurately measure the baseline isotopic signature required in models detecting the carbon source utilised in food web studies (Hamilton et al. 2005; Cole et al. 2011; Smyntek et al. 2012). Isotope signatures of terrestrial, littoral and pelagic sources can overlap considerably preventing source discrimination. In addition, mobile predators can integrate carbon from a number of sources resulting in a mixed dietary pattern which can be difficult to explain (Layman et al. 2012; Phillips et al. 2014). Allochthony in higher trophic levels may therefore not be detected. While the terrestrial subsidy of food webs can sometimes be established, the age (and therefore biochemical/nutrient quality) of carbon cannot be determined using stable isotopes alone.

\section{Radiocarbon in the food web}

Radiocarbon $\left({ }^{14} \mathrm{C}\right)$ has utility for examining freshwater carbon dynamics. $\Delta^{14} \mathrm{C}$ (see methods for derivation) of freshwater carbon is governed by its source and is corrected for fractionation, removing the problem of kinetic fractionation experienced in stable isotope analyses. "Modern/Recent" (atmospheric, modern photosynthetic terrestrial plant production) radiocarbon will be equivalent to that of the modern atmosphere. "Labile" terrestrial carbon can be derived from terrestrial material that has undergone minor decomposition. Complex soil/peat dynamics can mean that although the carbon is chemically labile, it may have a lower than modern radiocarbon content (Trumbore 2009). Therefore, carbon that is ${ }^{14} \mathrm{C}$ depleted, relative to modern values may still be labile, despite its age, and available for microbial catabolisation.

Due to soil carbon cycling and turnover, carbon can take decades to be released from subsurface soil (Trumbore et al. 1989; Polsenaere et al. 2013). As such, carbon is released which contains "Bomb" radiocarbon, enriched relative to the modern atmosphere due to nuclear testing in the $1950 \mathrm{~s}$ and $1960 \mathrm{~s}$, resulting in positive $\Delta^{14} \mathrm{C}$ values (Reimer et al. 2004). 
"Sub-fossil" carbon originates from stored terrestrial soil/peat carbon which can be substantially ${ }^{14} \mathrm{C}$-depleted depending on its age and mineralogy, which may be significantly degraded (Neff et al. 2006; Guo et al. 2007; Raymond et al. 2007; Caraco et al. 2010; Butman et al. 2012; Raymond et al. 2013).

The $\Delta^{14} \mathrm{C}$ value of dissolved inorganic carbon (DIC) (and autotrophic producers utilising DIC) may be partially derived from the weathering of carbonaceous bedrock (via atmospheric $\mathrm{CO}_{2}$ or soil carbon) with no radiocarbon content (" ${ }^{14} \mathrm{C}$ dead"). This leads to depleted ${ }^{14} \mathrm{C}$ values and a radiocarbon ages older than the contemporary atmosphere. This difference is known as a freshwater reservoir offset "FRO” (Deevey et al. 1954; Broecker and Orr 1958; Broecker and Walton 1959; Ascough et al. 2007; Ascough et al. 2010; Keaveney and Reimer 2012).

Radiocarbon and stable isotope measurements of autotrophs and their consumers can be therefore be used to determine the age and contributions of autochthonous and terrestrial carbon to the food web. A study was carried out using radiocarbon and SIA to identify the carbon sources utilised in a complex lake to determine the age and influence of terrestrial carbon subsidies of the food web.

\section{STUDY SITE AND METHODS}

Study site

Carbon dynamics in Lower Lough Erne (Figure 1) are complicated by seasonal changes in terrestrial subsidies and productivity (Keaveney et al. 2015). The lake was chosen as a suitable study site to build on the substantial amount of research carried out in the lake (Maguire and Gibson 2010). A radiocarbon study (using fish and water samples) was carried out in the lake that showed an FRO of ca. $500{ }^{14} \mathrm{C}$ years was present due to the alkalinity of the lake (Keaveney and Reimer 2012). While the FRO was relatively large, it was lower than 
would have been predicted from the hardness of lake water; most likely due to the contribution of younger allochthonous organic carbon in the lacustrine food web.

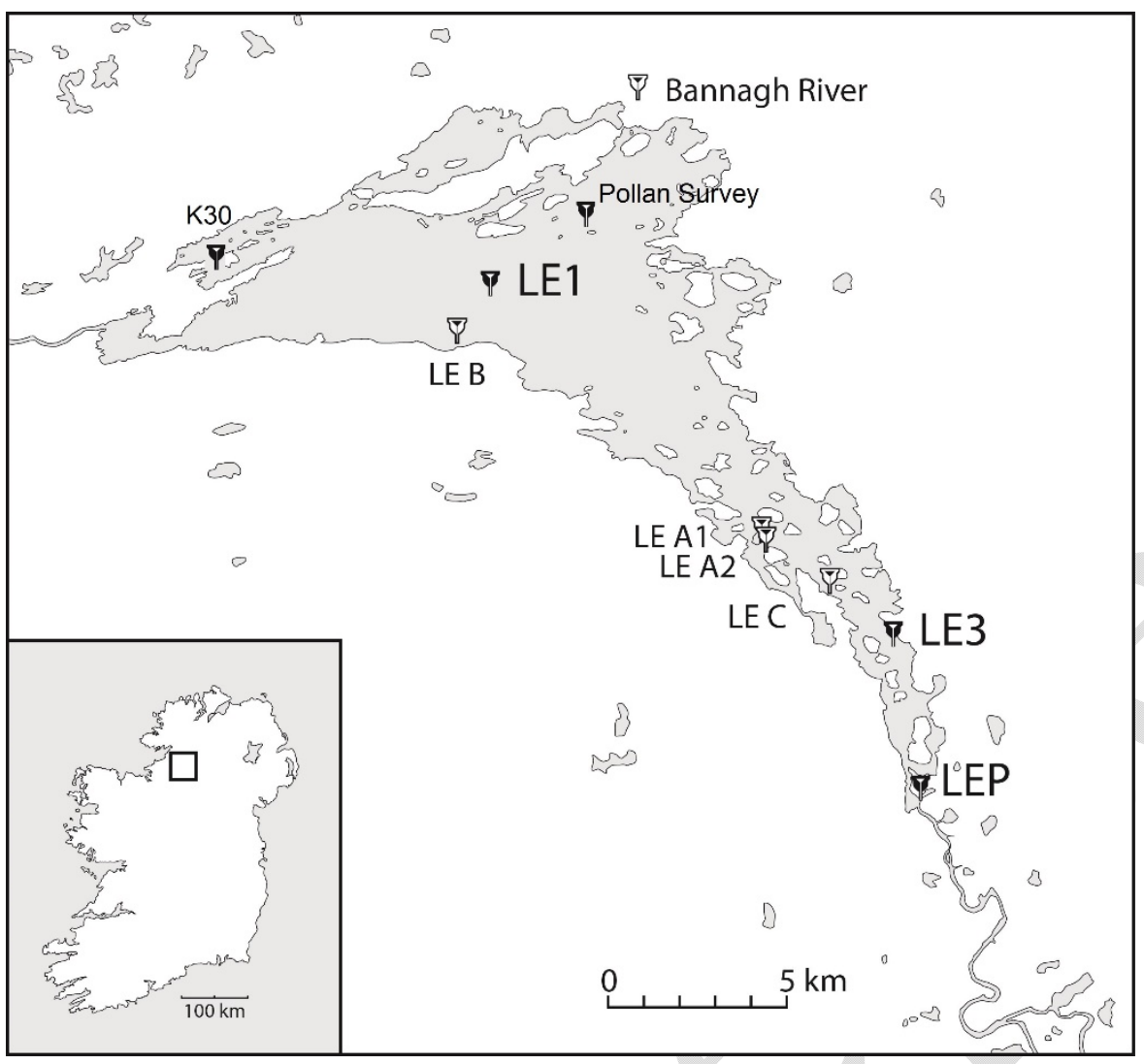

Figure 1 Lower Lough Erne, Fermanagh, Northern Ireland. River Bannagh and lake sites that were sampled are marked on the map. LE1, LE3 and LEP are pelagic sites, LEA1-LEC are littoral sites

Lough Erne in Northwest Ireland is a system composed of two interconnected lakes. The limnology of the system has been well studied since the 1970s (Gibson et al. 1980; Gibson et al. 1993; Zhou et al. 2000; Gibson et al. 2003; Gibson et al. 2005; Maguire and Gibson 2010). It is a relatively large, humic (DOC c. $12 \mathrm{mg} \mathrm{l}^{-1}$ ) and alkaline lake (alkalinity $\approx 1.5$ meq $\left.1^{-1}\right)$. The lake is eutrophic on the basis of total phosphorous (TP) $\left(>50 \mu \mathrm{g} \mathrm{L}^{-1}\right.$ since 1975 (Battarbee 1986; Foy et al. 1993; Maguire and Gibson 2010) but light limitation due to high DOC loading results in secchi depths of $1-3 \mathrm{~m}$.

Chlorophyll a concentrations were reduced due to the presence of zebra mussels (Dreissena morpha) (Foy et al. 1993; Maguire and Gibson 2010) since the late 1990s (Rosell et al. 1998). Expanding zebra mussel population with associated decreases in phytoplankton abundance have been shown by stable isotope analysis to shift Lower Lough Erne 
zooplankton production towards greater allochthony (Maguire and Grey 2006). There is no indication in these studies whether this terrestrial carbon is derived from modern or detrital material.

\section{Field Sampling}

\begin{tabular}{|c|c|c|c|}
\hline Site ID & Coordinates & & \\
\hline River Bannagh & $54^{\circ} 32^{\prime} 02^{\prime \prime} \mathrm{N}$ & $7^{\circ} 46^{\prime} 55^{\prime \prime} \mathrm{W}$ & \\
\hline LE1 & $54^{\circ} 29^{\prime} 07^{\prime \prime} \mathrm{N}$ & $7^{\circ} 50^{\prime} 37^{\prime \prime} \mathrm{W}$ & \\
\hline LE3 & $54^{\circ} 23^{\prime} 51^{\prime \prime} \mathrm{N}$ & $7^{\circ} 40^{\prime} 12^{\prime \prime} \mathrm{W}$ & \\
\hline LEP & $54^{\circ} 21^{\prime} 30^{\prime \prime} \mathrm{N}$ & $7^{\circ} 39^{\prime} 40^{\prime \prime} \mathrm{W}$ & \\
\hline LEA1 \& 2 & $54^{\circ} 23^{\prime} 09^{\prime \prime} \mathrm{N}$ & $7^{\circ} 40^{\prime} 08^{\prime \prime} \mathrm{W}$ & \\
\hline LEB & $54^{\circ} 28^{\prime} 20^{\prime \prime} \mathrm{N}$ & $7^{\circ} 51^{\prime} 51^{\prime \prime} \mathrm{W}$ & \\
\hline LEC & $54^{\circ} 24^{\prime} 38^{\prime \prime} \mathrm{N}$ & $7^{\circ} 41^{\prime} 50^{\prime \prime} \mathrm{W}$ & \\
\hline & \multicolumn{2}{|c|}{ Irish Grid Reference } & Depth \\
\hline K30 & \multicolumn{2}{|c|}{025607} & 1 to $4 \mathrm{~m}$ \\
\hline Pollan Survey (PS) & \multicolumn{2}{|c|}{110610 to 130600} & 20 to $30 \mathrm{~m}$ \\
\hline
\end{tabular}

Table 1: Location data for sampling sites including depths of fish net placement.

Field sampling was conducted in February, March, May, August and October of 2011 and details of methodology are described in supplemental information (also, Keaveney et al. 2015). The lake did not stratify during the study. DIC, DOC, POM, phytoplankton and zooplankton were isolated from water samples collected at sites LE1, LE3 and LEP (Figure 1, Table 1).

Littoral invertebrates were sampled once in July 2011 at 3 sites (Figure 1), using hand searches and $300 \mu \mathrm{m}$ dip nets. Biofilm was collected from macrophyte stems and the upper surface of rocks using a toothbrush with matter rinsed into sample containers using Milli-Q® water.

Fish samples were obtained from routine surveys conducted for population and biomass studies at a number of spatially distinct sites carried out by the Agricultural and Food Biosciences Institute. Fish were caught using gill nets in 2010 using the survey methodology described by Rosell (2000) and were stored frozen prior to sampling for isotope samples. 


\section{Laboratory Sample preparation}

Samples were pre-treated and combusted for radiocarbon and stable isotope analysis as described in (Keaveney et al. 2015). The opercular bone obtained from fish samples was demineralised using $4 \% \mathrm{HCl}$ for approximately 24 hours until $\mathrm{CO}_{2}$ evolution was no longer evident. Paired opercular bones were homogenised using a Retsch MM200 Mixer Mill for SIA; lipid removal was deemed unnecessary based on previous work in the lake (Keaveney and Reimer 2012).

\section{Isotopic measurements:}

The ${ }^{14} \mathrm{C} /{ }^{12} \mathrm{C}$ ratio of the sample relative to an international standard $\left(\mathrm{F}^{14} \mathrm{C}\right)$ and its associated uncertainty were calculated according to Reimer et al. (2004) and van der Plicht \& Hogg (2006) and incorporated a fractionation correction (Stuiver and Polach 1977) based on $\delta^{13} \mathrm{C}$ measured by AMS.

$\Delta{ }^{14} \mathrm{C}$ is defined in Stuiver and Polach (1977) as the relative difference between the absolute international standard (base year 1950) and sample ${ }^{14} \mathrm{C} /{ }^{12} \mathrm{C}$ ratio corrected for age and $\delta^{13} \mathrm{C}$ fractionation. The $\Delta^{14} \mathrm{C}$ age correction accounts for decay that took place between collection/death and the time of measurement so that two measurements of the same sample taken years apart will produce the same $\Delta^{14} \mathrm{C}$ result, which is calculated using the equation: $\Delta^{14} \mathrm{C}=\left[\mathrm{F}^{14} \mathrm{C} * \mathrm{e}^{\lambda(1950-\mathrm{x})}-1\right] * 1000$

$\mathrm{X}$ is the year of collection or growth (2010 for fish samples analysed, 2011 for all other samples).

The AMS $\delta^{13} \mathrm{C}$ measurements (not given) include any fractionation which may occur during sample preparation and AMS analysis and therefore are only used for fractionation correction. All other stable isotope measurements were made using a Thermo Scientific EAIRMS. Samples were corrected using a one point calibration (R041 L-Alanine). Other standards were measured at intervals (USGS 41 and Leucine) and results plotted to make a 
two point calibration. The effect of applying one point and two point correction to samples was compared and the difference was negligible. The precision of the EA-IRMS is $<0.1 \%$ for $\delta^{13} \mathrm{C}$ and $<0.15 \%$ for $\delta^{15} \mathrm{~N}$. Isotope values were expressed relative to the known standards $\left(\delta^{13} \mathrm{CVPDB}_{\mathrm{V}}, \delta^{15} \mathrm{~N}_{\mathrm{AIR}}\right)$.

\section{Statistical Analyses.}

In order to determine the percentage contribution of sources to the diet of Lower Lough Erne fish, mixing models were generated using SIAR (version 4.2) (Parnell et al. 2008), a Bayesian isotope mixing model in $\mathrm{R}$ (version 2.12.1). The model utilises mean stable isotope values and associated standard deviations from dietary sources to generate a mixing model which incorporates these uncertainties associated with multiple sources.

Trophic enrichment factors (TEF) were $\Delta^{13} \mathrm{C}=1.63 \pm 0.5 \%, \Delta^{15} \mathrm{~N}=2.9 \pm 0.32 \%$ (Caut et al. 2009). SIAR models have been criticised for sensitivity to variable trophic enrichment factors, which in this study were obtained from the literature (Caut et al. 2009; Bond and Diamond 2011; Phillips et al. 2014). Changes made to the TEF when generating SIAR models with data from this study had little influence on the results of the model. However, large differences in stable isotope signatures can make the model less sensitive to trophic enrichment factors (Jensen et al. 2012). As such the model was thought unreliable for radiocarbon data and was only utilised and assumed to be robust for stable isotope data. Models were generated from measurements of the largest fish groups (perch: Perca fluviatilis, pollan: Coregonus autumnalis and roach: Rutilis rutilis) and source prey collected from Lower Lough Erne in 2011. Data utilised in models may be found in supplemental information. All other statistics (regression, ANOVA) were performed in R using HMisc (version 3.14-0 (Harrell Jr et al. 2007)) and ggplot (version 0.9.3.1 (Ginestet 2011) packages. 


\section{RESULTS}

Lower Lough Erne Fish

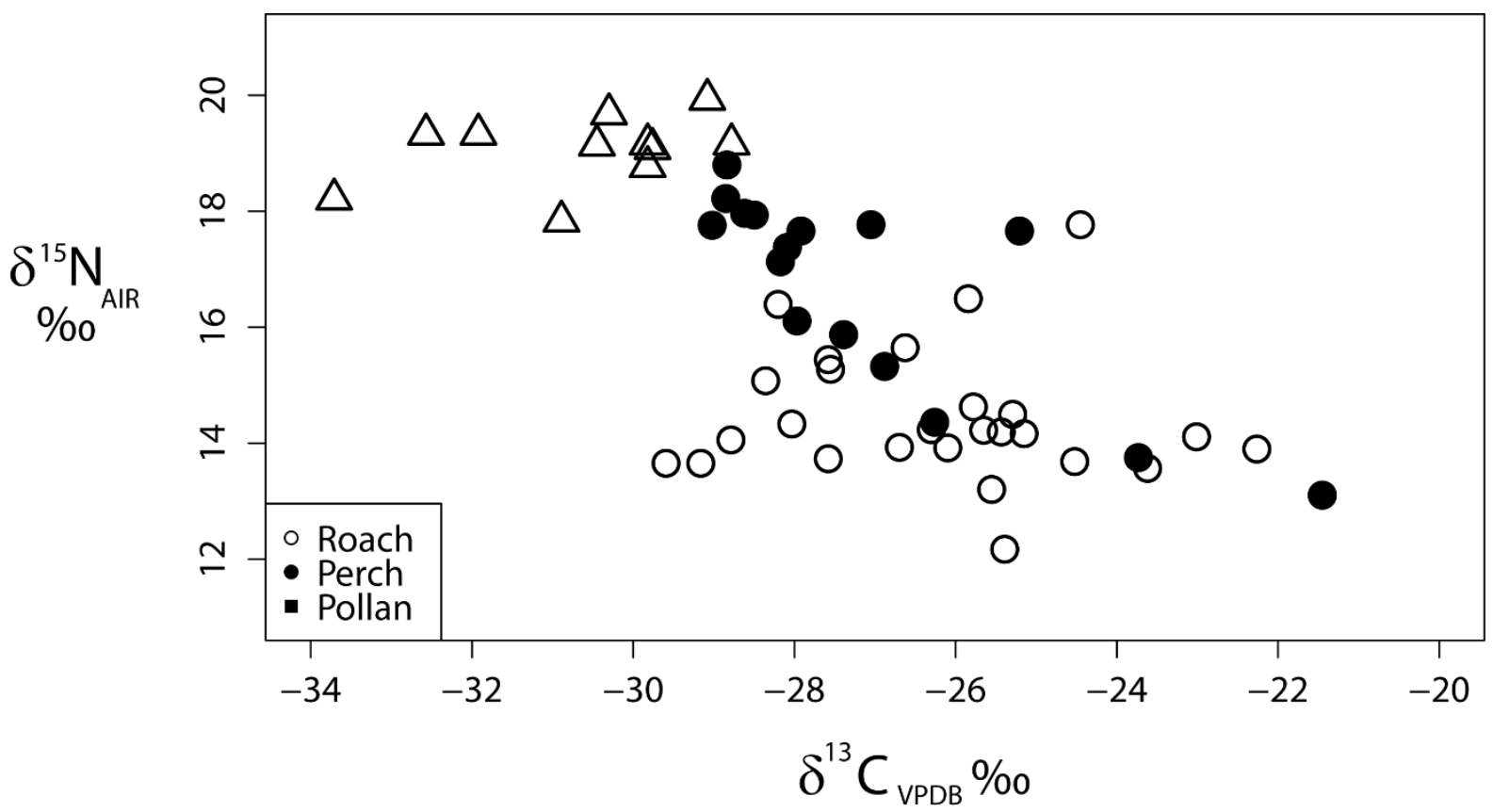

Figure 2 Stable carbon and nitrogen isotope results from Lower Lough Erne fish species collected in 2010.

Stable isotope analyses of Lower Lough Erne fish show distinct differences between species

(Figure 2). Samples from deep water surveys (20-30 m, Table 1) - Pollan (Coregonus

autumnalis, $\mathrm{n}=11$ ) and trout (Salmo trutta, $\mathrm{n}=3)$ were ${ }^{13} \mathrm{C}$-depleted $\left(\delta^{13} \mathrm{C}<-28 \%\right.$ ). Elevated $\delta^{15} \mathrm{~N}(>17 \%$ ) suggests the fish are more predatory than others measured in the study. Perch (Perca fluviatilis, $\mathrm{n}=16$ ) collected in the same location had similarly elevated $\delta^{15} \mathrm{~N}$, yet perch were also more ${ }^{13} \mathrm{C}$-enriched than pollan and trout. The $\delta^{13} \mathrm{C}$ values of perch collected in a shallower, more littoral sample (depth $<4 \mathrm{~m}$ ) vary from -29.0 to $-21.5 \%$; $\delta^{15} \mathrm{~N}$ values also differ (13.1 to $18.6 \%$ ). Perch stable isotope results indicate a more mixed diet than pollan or trout with smaller fish feeding in the littoral area. Roach (Rutilis rutilis, $\mathrm{n}=26$ ) isotopes also fluctuate showing a mixed diet with a littoral influence. 

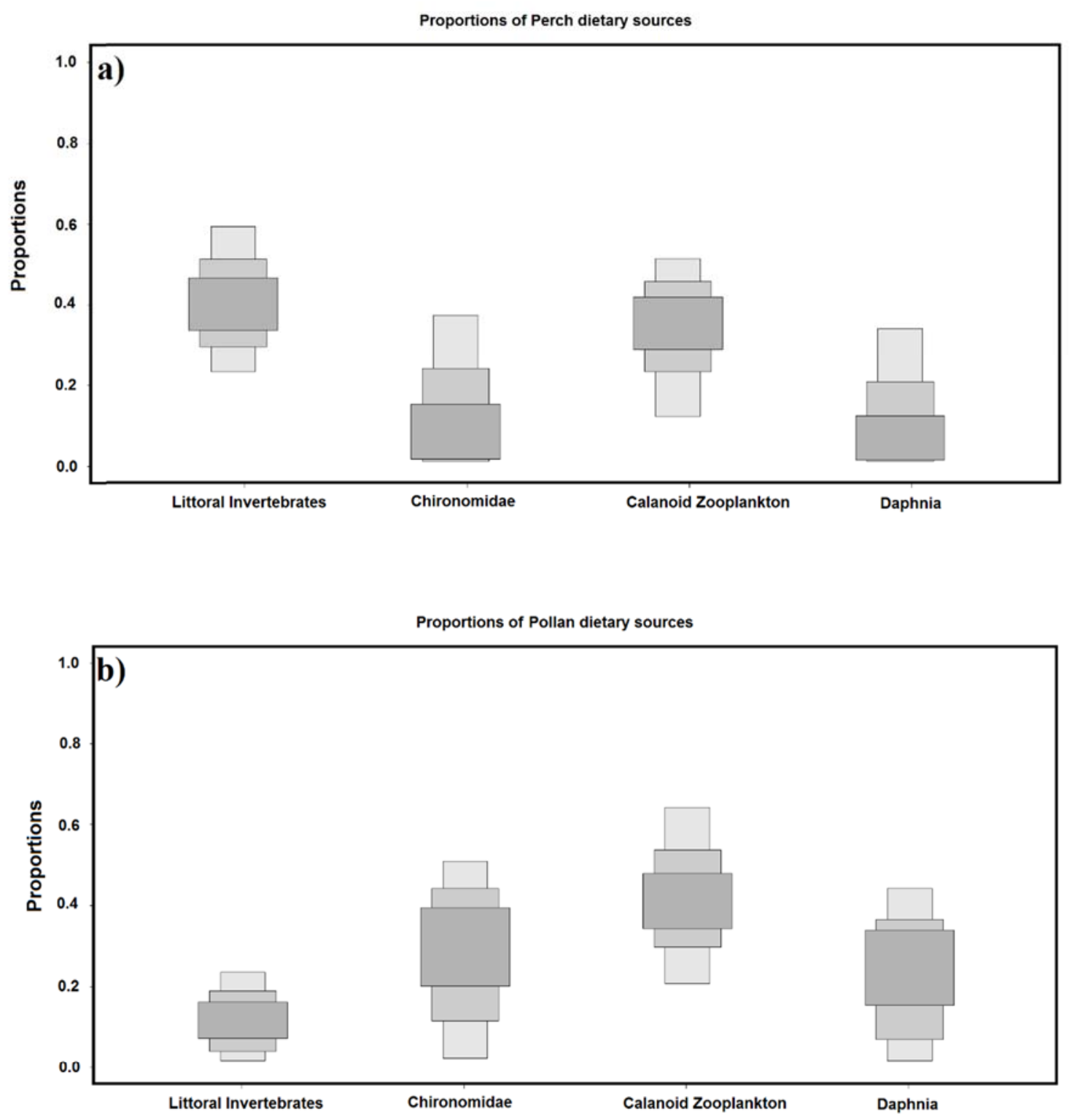

Proportions of Roach dietary sources

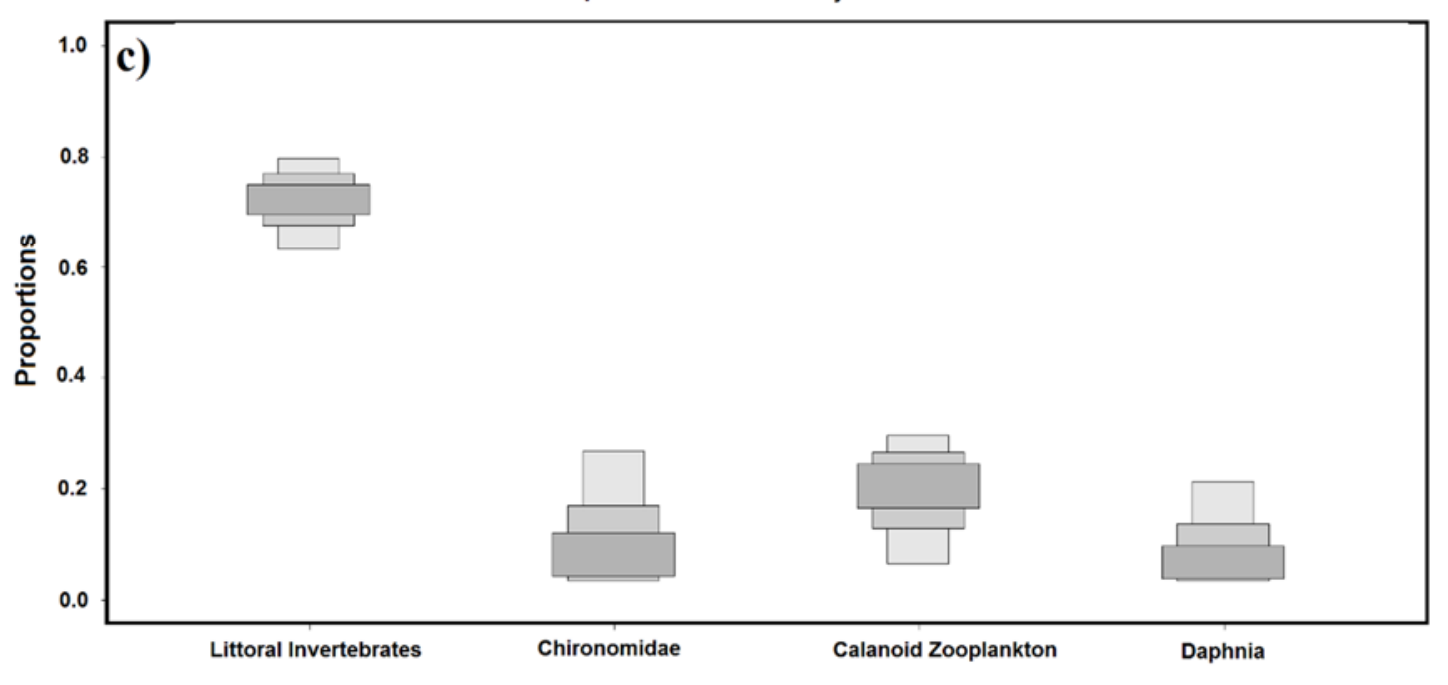


Figure 3 a-c: Proportions of dietary sources contributing to the diets of perch (Perca fluviatilis, Figure 3a), pollan (Coreganus autumnalis, Figure 3b) and roach (Rutilis rutilis, Figure 3c). Mixing models were generated using SIAR version 4.2, $R$ version 2.12.1 and are described in more detail in the text. Shaded grey levels in plot refer to 5, 25, 75 and $95 \%$ confidence intervals.

Based on the outputs generated in the mixing model, sources (labelled in Figure 3, detailed values in supplemental information) contribute to the diet in different proportions according to species. Littoral invertebrates $(n=21)$ constitute approximately $23-61 \%$ of perch diet (Figure $3 a$ ), $0-23 \%$ of pollan diet (Figure $3 b$ ) and $62-79 \%$ of roach diet (Figure $3 c$ ). Pollan diet as indicated by the mixing model is strongly influenced by calanoid zooplankton $(19-62 \%)$ and to a lesser extent Daphnia spp. (1.4 - 33\%). Percentage contributions of sources to diet listed in the text are measured at $95 \%$ confidence level and data can be found in supplementary information.

In short, as indicated by the stable isotope data (Figure 2) the mixing model suggests that pollan have less influence from littoral sources than perch which have a more evenly mixed diet. Roach have the highest littoral contribution to their diet. However, the variation evident in the mixing model results, although due to source sample size issues, is evidence of the issues of stable isotope analysis and the clarity of conclusions that can be drawn from such data.

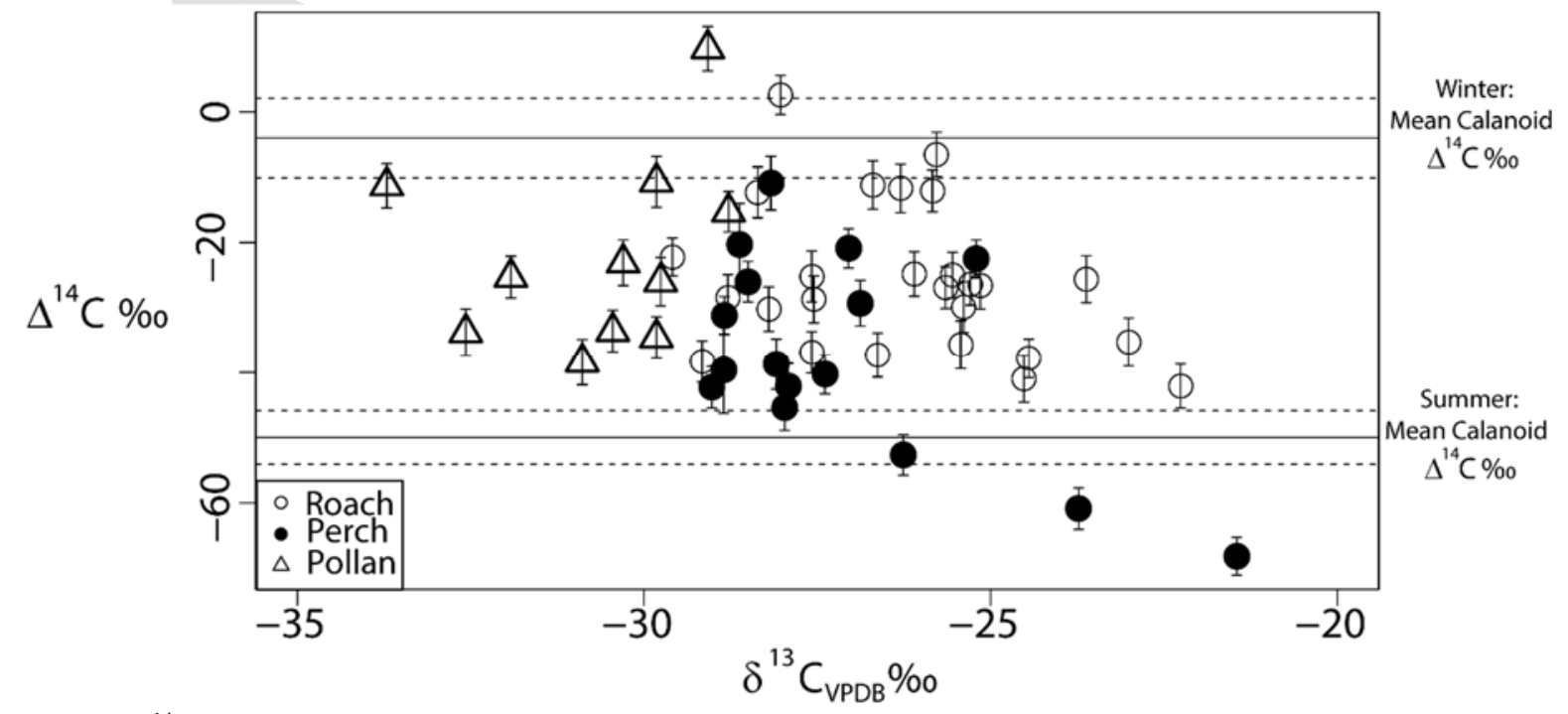

Figure 4: $\Delta^{14}$ Cand stable carbon isotope measurements from Lower Lough Erne fish. Error bars represent the 
uncertainty on measurements. Horizontal lines denote the mean $\Delta^{14} \mathrm{C}$ as measured from calanoid zooplankton in winter and summer. Winter calanoid $\Delta^{14} \mathrm{C}$ results are analogous to those of modern terrestrial carbon, summer to autochthonous algal $\Delta^{14} \mathrm{C}$.

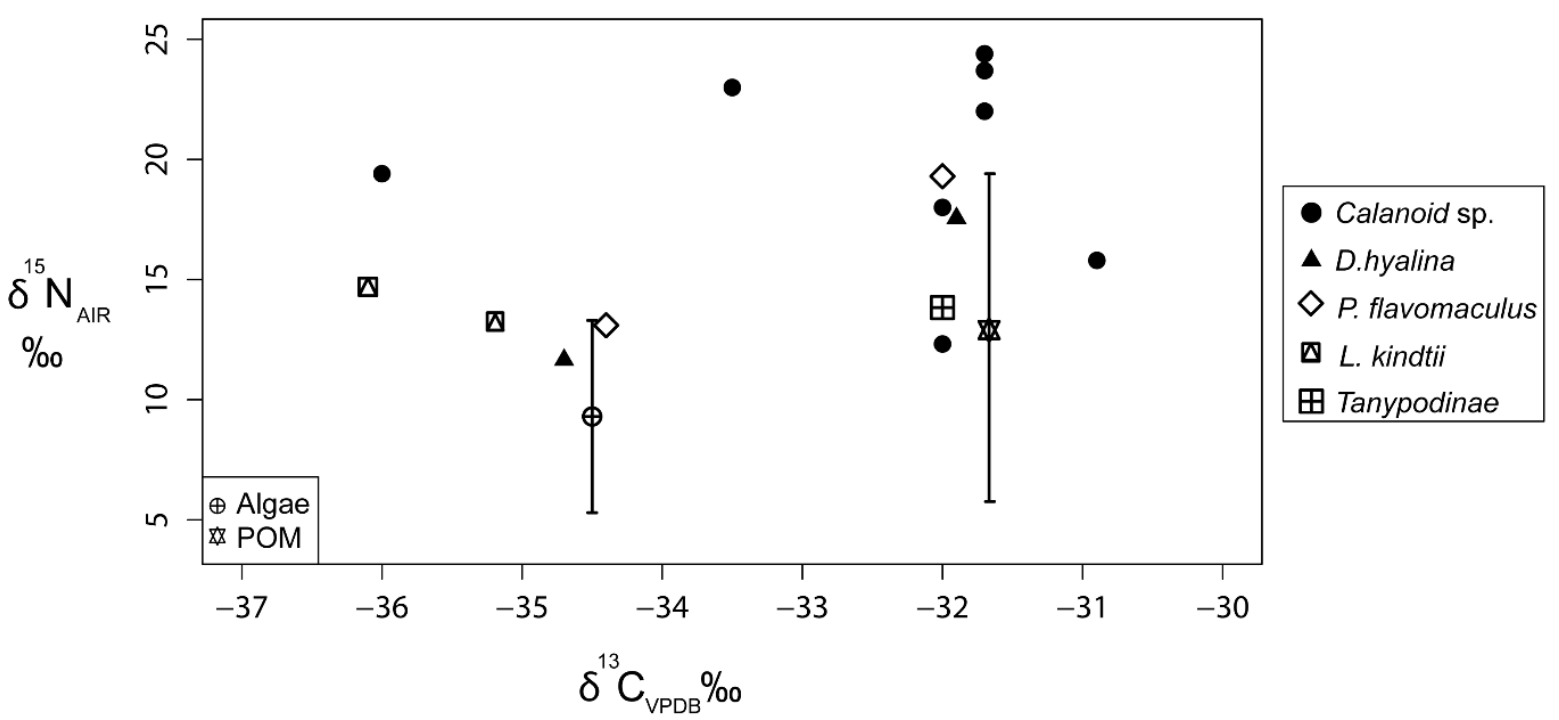

Figure 5: Stable isotope values of Lower Lough Erne pelagic invertebrate species. Points with error bars denote mean algal and POM isotope values with their associated standard deviations.

The sample size of stable isotope measurements of some sources was small, but the sample size of radiocarbon measurements for these sources was smaller still (see supplementary information). Large ranges of $\Delta^{14} \mathrm{C}$ values within a consumer/prey cohort lead to high standard deviations, again affecting the reliability of the model; consequently the model results are not presented here.

Figure 4 however gives an indication of the differences in the dietary information provided by the utilisation of $\Delta{ }^{14} \mathrm{C}$ measurements not shown by SIA. Error bars represent the statistical uncertainty of $\Delta^{14} \mathrm{C}$ measurements. There is no correlation between $\delta^{13} \mathrm{C}$ and $\Delta^{14} \mathrm{C}\left(\mathrm{R}^{2}=0.05\right.$, $\mathrm{p}=0.0885)$. The variation in species suggests there is no relationship between collection location and individual species $\Delta{ }^{14} \mathrm{C}$ value (ANOVA, $\mathrm{F}=0.765, \mathrm{p}=0.3856$ ).

It is clear from radiocarbon measurements that individual fish from all species utilise divergent carbon sources. $\Delta^{14} \mathrm{C}$ of the majority of fish are enriched relative to summer calanoid $\Delta{ }^{14} \mathrm{C}$. Three small perch $(\mathrm{TL}=9 \mathrm{~cm}, 9.3 \mathrm{~cm}, 9.4 \mathrm{~cm})$ have the most depleted $\Delta{ }^{14} \mathrm{C}(-$ $68.2 \%$, $-52.7 \%$ and $-60.8 \%$ respectively). 


\section{Invertebrate diet}

Stable isotope analysis of Lower Lough Erne invertebrates demonstrates distinction between groups of invertebrates (Figure 5). ${ }^{15} \mathrm{~N}$ values $($ winter $=23.4 \pm 1.2 \%$, summer $=16.6 \pm 3.7$ \%) of the calanoid zooplankton Eudiaptomus gracilis samples in winter are highly enriched relative to phytoplankton, POM and the other components of the food web including predatory fish and while they drop in summer they are still higher than expected from an algal diet. E. gracilis is an omnivorous species which preferentially feeds on phytoplankton (Maguire and Grey 2006; Ger et al. 2011). Their $\delta^{13} \mathrm{C}$ (winter $=-32.3 \pm 2.5 \%$, summer $=$ $33.4 \pm 2.4 \%$ is inconclusive - it could describe an algal $\left(\delta^{13} \mathrm{C}=-33.4 \pm 3.8 \% 0, \delta^{15} \mathrm{~N}=9.3 \pm\right.$ $4.7 \%$ ) or particulate organic matter $\left(\delta^{13} \mathrm{C}=-31.4 \pm 1.3 \%\right.$, $\delta^{15} \mathrm{~N}=13.4 \pm 7.3 \%$ carbon source. Their $\Delta^{14} \mathrm{C}$ values are more clear - winter values are enriched and within the range of lake DOC values (mean winter calanoid $\Delta^{14} \mathrm{C}=-4.0 \pm 6.1 \%$ ). However, the summer results are within range of algal sample $\Delta^{14} \mathrm{C}$ values $\left(\Delta^{14} \mathrm{C}=-50 \pm 4.1 \%\right)$.

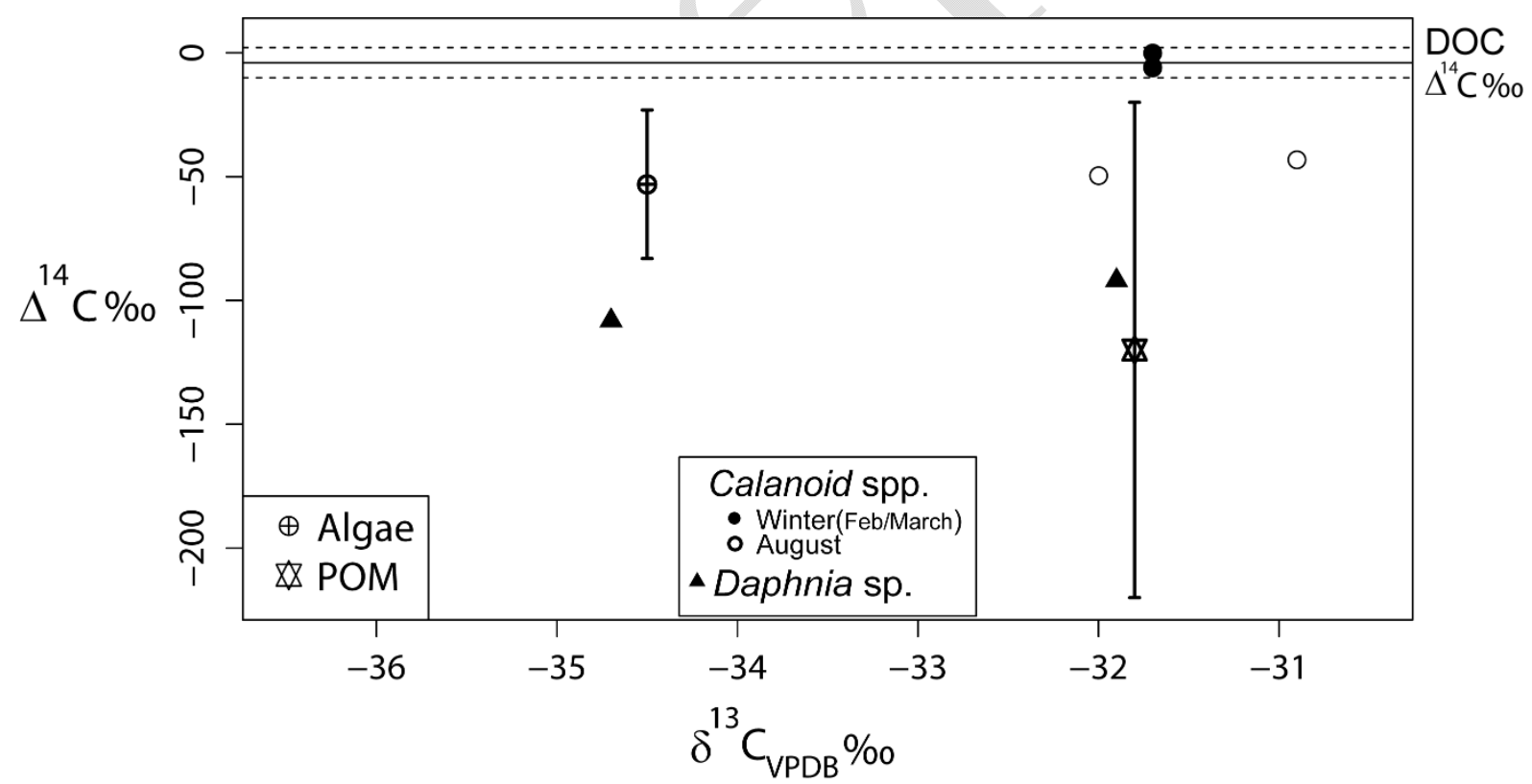

Figure 6: Invertebrate $\triangle^{14} \mathrm{C}$ and $\delta^{13} \mathrm{C}$ measured from selected Lower Lough Erne invertebrate species. Winter samples were collected in February and March, and summer samples in May and August 2011. Points with error bars denote mean algal and POM isotope values with their associated standard deviations. Mean DOC $\Delta^{14} \mathrm{C}$ (relatively consistent over the duration of the study) is shown as a horizontal line $-\delta^{13} \mathrm{C}$ values were unreliable for DOC samples. Dashed lines denote the error associated with the mean.

Daphnia spp. ${ }^{15} \mathrm{~N}$ is also enriched but more so in the summer $\left(\delta^{15} \mathrm{~N}\right.$ in winter $=+12.8 \pm 1.7$ $\%$, summer $=+17.5 \%$ ) despite increased algal abundance. Daphnia $\Delta^{14} \mathrm{C}$ values (Figure 6) 
are depleted $\left(\Delta^{14} \mathrm{C}=-108.1 \pm 5.2 \%-91.9 \pm 3.6 \%\right)$ and are within the range of sub-fossil POM values $\left(\Delta^{14} \mathrm{C}=-83.1 \pm 4.0\right.$ to $-191.9 \pm 12.4 \%$ ) .

\section{DISCUSSION}

The results from Lower Lough Erne samples show evidence three dietary carbon sources exist in the lake.

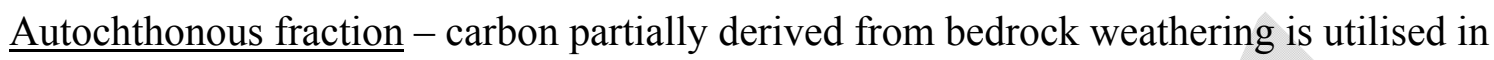
primary production leading to a mean algal value of $\Delta^{14} \mathrm{C}=-58.8 \pm 9 \%$ (excluding May cyanobacteria sample). This ${ }^{14} \mathrm{C}$-depletion results from the freshwater reservoir offset and is linked to water alkalinity (Keaveney and Reimer 2012).

Modern/recent Radiocarbon: Riverine DOC sampled in October 2011 had a positive bomb radiocarbon signal $\left(\Delta^{14} \mathrm{C}=+51.9 \pm 2.9 \%\right)$ indicating a modern or recent photosynthetic carbon source (Levin et al. 2013).

Labile allochthonous carbon: Lake DOC is ${ }^{14} \mathrm{C}$-enriched $\left(\Delta{ }^{14} \mathrm{C}=-17.4 \pm 19.4 \%\right.$ \% $)$ relative to DIC and POC in the lake, yet depleted relative to modern values. It is consistent with that from incoming River Bannagh in winter indicating a terrestrial source.

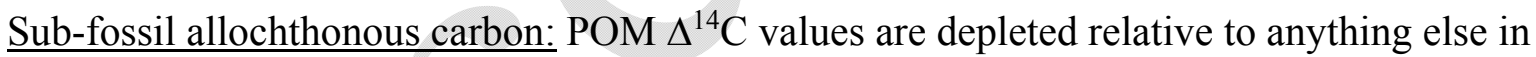
the lake indicating the presence of a sub-fossil terrestrial carbon source in the lake $\left(\Delta^{14} \mathrm{C}=\right.$ $122.3 \pm 61.3 \%$ )

\section{Invertebrate food web}

While the sample size of invertebrate prey was small, there is clear evidence that terrestrial support of the food web is extensive. Invertebrates utilise both energetically rich autochthonous and terrestrial carbon of lower nutritional value. Within the terrestrial carbon pool both sub-fossil, detrital carbon with low nutrient value, and chemically labile carbon are consumed by different invertebrates. 
The highly positive $\delta^{15} \mathrm{~N}$ values of calanoid zooplankton indicate the presence of a microbial loop with bacteria metabolising terrestrial carbon which is then consumed by other species (Meyer 1994). The existence of a microbial loop is an indicator of a terrestrial diet but stable isotope analysis does not indicate whether the terrestrial source utilised by Lower Lough Erne calanoid zooplankton is detrital, or whether it is a labile terrestrial carbon source.

$\Delta{ }^{14} \mathrm{C}$ values of calanoid zooplankton measured in winter and summer demonstrate the significant differences in carbon sources utilised (Figure 6). $\Delta^{14} \mathrm{C}$ measurements from winter calanoid zooplankton (winter $=-7.5 \pm 14.7 \%$ ) are within the range of lake DOC $\Delta^{14} \mathrm{C}(-4$ to $40 \%$, Figure 6). In the summer, calanoid $\Delta^{14} \mathrm{C}$ values are comparable to algal $\Delta^{14} \mathrm{C}$, showing a clear dietary switch with algal blooms. The calanoid invertebrates are clearly selecting bioenergetically richer carbon - labile terrestrial carbon in the winter with low algal abundance and a switch to an algal diet in the summer. They are not utilising sub-fossil carbon sources showing a clear selection against detrital carbon.

Daphnia $\Delta^{14} \mathrm{C}$ values are more depleted than algal $\Delta^{14} \mathrm{C}$. Daphnia have been shown to feed on the algal portion of the POM (Rautio et al. 2011). However, Daphnia $\Delta^{14} \mathrm{C}$ values indicate that they are consuming a sub-fossil carbon source which is older than the algal carbon pool suggesting that they are also feeding on a detrital terrestrial portion of POM.

The availability and biochemical quality of carbon seems to drive the dietary preferences of calanoid zooplankton, while Daphnia spp. derive carbon from particulate sources of detrital sub-fossil carbon.

\section{Fish}

The stable isotope values of fish are as expected; benthic/planktonic pollan have a strongly predatory signal and their isotope values reflect their specialised diets. Roach and perch, again as expected have a more mixed littoral and pelagic diet showing their less selective diet. The evidence for terrestrial subsidy of fish diet is not as clear when using SIA alone as 
$\delta^{13} \mathrm{C}$ overlaps with terrestrial values. The evidence for terrestrial support of all fish species is only found in the results from radiocarbon analysis.

A range of $\Delta^{14} \mathrm{C}$ values are evident in individual Lower Lough Erne fish. While stable isotopes can indicate that terrestrial carbon may be a component of diet of Lower Lough Erne invertebrates, $\Delta{ }^{14} \mathrm{C}$ clearly shows that individual fish within and between species can obtain carbon through different food web pathways including those supported by terrestrial carbon. Even $\Delta^{14} \mathrm{C}$ values of open/deep water fish (e.g. pollan) are enriched indicating that terrestrial carbon has been transferred to the highest trophic levels.

An individual pollan and roach each had positive $\Delta^{14} \mathrm{C}$ values indicating the presence of bomb radiocarbon in their diet. No invertebrate species measured in this study had an equivalent bomb radiocarbon signal. However, DOC from a tributary river to Lower Lough Erne, the River Bannagh (see Figure 1), collected in October 2011, had a highly positive $\Delta^{14} \mathrm{C}$ $\left(=+51 \pm 2.9 \%\right.$ ) which corresponds to atmospheric ${ }^{14} \mathrm{C}$ from $2005-2009$ (Hua and Barbetti 2004; Levin and Kromer 2004; Levin et al. 2008; Levin et al. 2013), so represents modern/recent photosynthetic carbon from leaf fall, grass or riparian plant material. A modern terrestrial carbon source is clearly a part of the food web of fish with positive $\Delta^{14} \mathrm{C}$ values although it is unclear the mechanism by which this carbon enters the food web. Enriched bomb $\Delta^{14} \mathrm{C}$ as seen in Lower Lough Erne can only be obtained from the products of a terrestrial plant or its consumer. Much of the shore line of the lake consists of shrubs or trees while the more sheltered bays have extensive beds of emergent macrophytes which could be contributing a source of modern carbon via leaf fall and plant senescence. The enriched $\Delta^{14} \mathrm{C}$ values of the individual pollan and roach show they must be utilising prey consuming this modern source of terrestrial material in addition to autochthonous and terrestrial food sources. This prey source is missing from our analysis; we did not measure 
any source contributing to diet other than riverine DOC that had sufficient enrichment to cause these $\Delta^{14} \mathrm{C}$ values.

The utilisation of methane can result in ${ }^{14} \mathrm{C}$-enriched/depleted results depending on the source of methane (Billett et al. 2012; Garnett et al. 2013). However, samples in Lower Lough Erne are not sufficiently ${ }^{13} \mathrm{C}$-depleted to provide evidence for methanogenesis in the system (Pasche et al. 2011). The absence of an enriched $\Delta{ }^{14} \mathrm{C}$ bomb signal in the pelagic invertebrate species measured in this study suggests that there may be a benthic source of modern carbon which was not sampled in the current study.

Perch have a mixed pelagic and littoral diet according to the relatively large range of $\delta^{13} \mathrm{C}$ values. The majority of perch $\Delta^{14} \mathrm{C}$ measurements fall within the range of those of zooplankton with an algal diet such as summer calanoid samples. They do not appear to have a sub-fossil carbon source; all except three are enriched relative to mean calanoid zooplankton $\Delta^{14} \mathrm{C}$. The exceptions are the three oldest perch which clearly have a prey source consuming a slightly older source of carbon although $\Delta^{14} \mathrm{C}$ indicates they are still within the range of autochthonous carbon sources. They were collected from K30 (Table 1), at a depth of 1-4 m. These perch are amongst the smallest and are likely to feed in the littoral zone - as indicated by the stable isotopes; $\Delta^{14} \mathrm{C}$ may also indicate a littoral carbon source (values are within $2 \sigma$ error of littoral zone food sources such as Asselus aquaticus $\left(\Delta^{14} \mathrm{C}=-57.3 \pm 3 \%\right.$ ) and biofilm $\left(\Delta^{14} \mathrm{C}=-56.6 \pm 12.2 \%\right)$.

Roach are omnivorous and this is clearly shown in the stable isotope and radiocarbon measurements. The range of $\Delta{ }^{14} \mathrm{C}$ values indicates they are consuming invertebrates feeding in terrestrial and/or autochthonous carbon pools. None are more depleted than algal $\Delta{ }^{14} \mathrm{C}$ indicating that terrestrial carbon is more important in the food web of roach. One roach, like the pollan sample, is enriched with bomb radiocarbon indicating they are consuming prey utilising a modern terrestrial carbon pool. 


\section{CONCLUSION}

The use of the radiocarbon method in analysing the Lower Lough Erne food web has elucidated the sources of carbon utilised in the lake. Terrestrial support of the food web was expected given previous research and water chemistry (e.g. DOC loading, chlorophyll $a$ values). The method allows for clear separation of modern/recent, labile and sub-fossil terrestrial carbon in addition to the partitioning of terrestrial and autochthonous carbon sources. The method also shows the extent to which the pelagic food web is driven by terrestrial carbon sources, to the highest trophic levels - terrestrial support is underestimated or overlooked with stable isotope analysis alone.

The distinction between modern, labile, and detrital, sub-fossil terrestrial carbon in the food web made using radiocarbon analysis is essential when analysing carbon dynamics in freshwater lakes. The data have implications for biodiversity management as the proliferation of invasive species takes place. Terrestrial subsidies of freshwater lakes are likely to increase with climate and land use changes; this information is of paramount importance in the overall management of freshwater areas, and their catchments in the near future.

We thank the staff of the 14CHRONO Centre at Queen's University Belfast, particularly Stephen Hoper and Ron Reimer for aid in stepped combustion and AMS 14C analysis. We also thank the staff of the Freshwater Lab and Agri-Environment Branch of AFBI who undertook lake sampling and water analyses and Chris Barry who was responsible for separating the biological samples and their identification. Thanks also to Gavin Marshall, Kieran MacOscar, and Robert Rosell for aid in fish sampling and information. Thanks to Barry Finnegan for additional help with sampling. We are grateful to the reviewers who provided valuable assistance in the preparation of this manuscript. We are happy to make our data available as supplemental information. Data associated with this study are also available as supplemental information in Keaveney et al., included in this issue. Funding for this work was provided by the Natural Environment Research Council, UK grant NE/I01666X/1.

\section{REFERENCES}

ÅGren A, Berggren M, Laudon H, Jansson M. 2008. Terrestrial export of highly bioavailable carbon from small boreal catchments in spring floods. Freshwater Biology 53(5):964-72. 
Ascough P, Cook G, Church M, Dunbar E, Einarsson Á, McGovern T, Dugmore A, Perdikaris S, Hastie H, Friðriksson A. 2010. Temporal and spatial variations in freshwater ${ }^{14} \mathrm{C}$ reservoir effects: Lake Mývatn, northern Iceland. Radiocarbon. 52(2-3):1098-112. Ascough PL, Cook GT, Church MJ, Dugmore AJ, McGovern T, Dunbar E, Einarsson E, Frioriksson A, Gestsdottir H. 2007. Reservoirs and radiocarbon: ${ }^{14} \mathrm{C}$ dating problems in Myvatnssveit, Northern Iceland. Radiocarbon 49(2):947-61.

Battarbee, R. W. 1986. The Eutrophication of Lough Erne Inferred from Changes in the Diatom Assemblages of ${ }^{210} \mathrm{~Pb}$-and ${ }^{137} \mathrm{Cs}$-Dated Sediment Cores. Proceedings of the Royal Irish Academy. Section B: Biological, Geological, and Chemical Science, 86, 141-168.

Billett MF, Garnett MH, Dinsmore KJ, Dyson KE, Harvey F, Thomson AM, Piirainen S, Kortelainen P. 2012. Age and source of different forms of carbon released from boreal peatland streams during spring snowmelt in E. Finland. Biogeochemistry 111(1-3):273-86. Bond AL, Diamond AW. 2011. Recent Bayesian stable-isotope mixing models are highly sensitive to variation in discrimination factors. Ecological Applications 21(4):1017-23.

Broecker WS, Orr PC. 1958. Radiocarbon chronology of Lake Lahontan and Lake Bonneville. Geological Society of America Bulletin 69(8):1009-32.

Broecker WS, Walton A. 1959. The geochemistry of C- ${ }^{14}$ in fresh-water systems. Geochimica et Cosmochimica Acta 16(1):15-38.

Butman D, Raymond PA, Butler K, Aiken G. 2012. Relationships between $\Delta^{14} \mathrm{C}$ and the molecular quality of dissolved organic carbon in rivers draining to the coast from the conterminous United States. Global Biogeochemical Cycles 26(4).

Caraco N, Bauer JE, Cole JJ, Petsch S, Raymond P. 2010. Millennial-aged organic carbon subsidies to a modern river food web. Ecology 91(8):2385-93.

Carpenter SR, Cole JJ, Pace ML, Van de Bogert M, Bade DL, Bastviken D, Gille CM, Hodgson JR, Kitchell JF, Kritzberg ES. 2005. Ecosystem subsidies: terrestrial support of aquatic food webs from ${ }^{13} \mathrm{C}$ addition to contrasting lakes. Ecology 86(10):2737-50.

Caut S, Angulo E, Courchamp F. 2009. Variation in discrimination factors $\left(\Delta^{15} \mathrm{~N}\right.$ and $\left.\Delta^{13} \mathrm{C}\right)$ : the effect of diet isotopic values and applications for diet reconstruction. Journal of Applied Ecology 46(2):443-53. 
Cole J, Carpenter S, Kitchell J. 2011. Strong evidence for terrestrial support of zooplankton in small lakes based on stable isotopes of carbon, nitrogen, and hydrogen.

de Kluijver A, Yu J, Houtekamer M, Middelburg JJ, Liu Z. 2012. Cyanobacteria as carbon source for zooplankton in eutrophic Lake Taihu, China, measured by ${ }^{13} \mathrm{C}$ labeling and fatty acid biomarkers. Limnology and Oceanography 57(4):1245.

Deevey ES, Gross MS, Hutchinson GE, Kraybill HL. 1954. The natural $\mathrm{C}^{14}$ contents of materials from hard-water lakes. Proceedings of the National Academy of Sciences of the United States of America 40(5):285.

Foy R, McGlynn K, Gibson C. Chlorophyll a and nutrients in Lough Erne; 1993. Biology and Environment, 93B, 163-174.

Fry B. 1991. Stable isotope diagrams of freshwater food webs. Ecology. 2293-7.

Garnett M, Hardie S, Murray C, Billett M. 2013. Radiocarbon dating of methane and carbon dioxide evaded from a temperate peatland stream. Biogeochemistry 114(1-3):213-23.

Ger KA, Panosso R, Luerling M. 2011. Consequences of acclimation to Microcystis on the selective feeding behavior of the calanoid copepod Eudiaptomus gracilis. Limnology and Oceanography 56(6):2103-14.

Gibson C, Foy R, Fitzsimons A. 1980. A limnological reconnaissance of the Lough Erne system, Ireland. Internationale Revue der gesamten Hydrobiologie und Hydrographie 65(1):49-84.

Gibson C, McCall R, Dymond A. 1993. Skeletonema subsalsum in a freshwater Irish lake. Diatom research 8(1):65-71.

Gibson C, Anderson N, Zhou Q, Allen M, Appleby P. Changes in sediment and diatom deposition in Lower Lough Erne c. 1920-90; 2003. The Royal Irish Academy. 31-9.

Gibson C, Foy R, McNally J. Stratification and Oxygen Depletion in Lower Lough Erne 1991-2000; 2005. The Royal Irish Academy. 81-6.

Ginestet C. 2011. ggplot2: Elegant Graphics for Data Analysis. Journal of the Royal Statistical Society: Series A (Statistics in Society) 174(1):245-6.

Gratton C, Donaldson J, Zanden M. 2008. Ecosystem linkages between lakes and the surrounding terrestrial landscape in northeast Iceland. 
Grey JJ, R. Sleep, D. 2001. Seasonal changes in the importance of the source of organic matter to the diet of zooplankton in Loch Ness, as indicated by stable isotope analysis.

Guillemette F, McCallister SL, Giorgio PA. 2013. Differentiating the degradation dynamics of algal and terrestrial carbon within complex natural dissolved organic carbon in temperate lakes. Journal of Geophysical Research: Biogeosciences 118(3):963-73.

Guo L, Ping C-L, Macdonald RW. 2007. Mobilization pathways of organic carbon from permafrost to arctic rivers in a changing climate. Geophysical Research Letters 34(13):L13603.

Hamilton SK, Sippel SJ, Bunn SE. 2005. Separation of algae from detritus for stable isotope or ecological stoichiometry studies using density fractionation in colloidal silica. Limnology and Oceanography: Methods 3:149-57.

Harrell Jr FE, Dupont MC, Hmisc D. 2007. The design package. R package version: 2.1.

Harrod C, Griffiths D, McCarthy T, Rosell R. 2001. The Irish Pollan, Coregonus autumnalis: options for its conservation. Journal of Fish Biology 59(sA):339-55.

Hua Q, Barbetti M. 2004. Review of tropospheric bomb ${ }^{14} \mathrm{C}$ data for carbon cycle modeling and age calibration purposes. Radiocarbon 46(3):1273-98.

Jensen H, Kiljunen M, Amundsen PA. 2012. Dietary ontogeny and niche shift to piscivory in lacustrine brown trout Salmo trutta revealed by stomach content and stable isotope analyses. Journal of fish biology 80(7):2448-62.

Keaveney EM, Reimer PJ. 2012. Understanding the variability in freshwater radiocarbon reservoir offsets: a cautionary tale. Journal of Archaeological Science 39(5):1306-16.

Keaveney EM, Reimer PJ, Foy RH. 2015. Young, old and weathered carbon: using radiocarbon and stable isotopes to identify carbon sources in an alkaline, humic lake. Radiocarbon 57

Kritzberg ES, Cole JJ, Pace MM, Granéli W. 2006a. Bacterial growth on allochthonous carbon in humic and nutrient-enriched lakes: results from whole-lake ${ }^{13} \mathrm{C}$ addition experiments. Ecosystems 9(3):489-99.

Kritzberg ES, Langenheder S, Lindström ES. 2006b. Influence of dissolved organic matter source on lake bacterioplankton structure and function-implications for seasonal dynamics of community composition. FEMS microbiology ecology 56(3):406-17. 
Lapierre J-F, Guillemette F, Berggren M, Del Giorgio PA. 2013. Increases in terrestrially derived carbon stimulate organic carbon processing and $\mathrm{CO}_{2}$ emissions in boreal aquatic ecosystems. Nature communications 4.

Layman CA, Araujo MS, Boucek R, Hammerschlag-Peyer CM, Harrison E, Jud ZR, Matich P, Rosenblatt AE, Vaudo JJ, Yeager LA. 2012. Applying stable isotopes to examine foodweb structure: an overview of analytical tools. Biological Reviews 87(3):545-62.

Levin I, Kromer B. 2004. The tropospheric ${ }^{14} \mathrm{CO}_{2}$ level in mid latitudes of the northern hemisphere (1959-2003). Radiocarbon 46(3):1261-71.

Levin I, Hammer S, Kromer B, Meinhardt F. 2008. Radiocarbon observations in atmospheric $\mathrm{CO}<\mathrm{sub}>2</$ sub $>$ : Determining fossil fuel $\mathrm{CO}_{2}$ over Europe using Jungfraujoch observations as background. Science of the Total Environment 391(2):211-6.

Levin I, Kromer B, Hammer S. 2013. Atmospheric $\Delta^{14} \mathrm{CO}_{2}$ trend in Western European background air from 2000 to 2012. Tellus B 65.

Maguire C, Gibson C. Ecological change in Lough Erne: Influence of catchment changes and species invasions; 2010.

Maguire CM, Grey J. 2006. Determination of zooplankton dietary shift following a zebra mussel invasion, as indicated by stable isotope analysis. Freshwater Biology 51(7):1310-9. Marty, Jérôme, and Dolors Planas. 2008. "Comparison of methods to determine algal $\delta^{13} \mathrm{C}$ in freshwater." Limnology and Oceanography: Methods 6.1 51-63.

McCallister SL, Giorgio PAd. 2008. Direct measurement of the $\delta^{13} \mathrm{C}$ signature of carbon respired by bacteria in lakes: Linkages to potential carbon sources, ecosystem baseline metabolism, and $\mathrm{CO}_{2}$ fluxes. Limnology and oceanography 53(4):1204.

Meyer J. 1994. The microbial loop in flowing waters. Microbial Ecology 28(2):195-9.

Neff J, Finlay J, Zimov S, Davydov S, Carrasco J, Schuur E, Davydova A. 2006. Seasonal changes in the age and structure of dissolved organic carbon in Siberian rivers and streams. Geophysical Research Letters 33(23).

Parnell A, Inger R, Bearhop S, Jackson A. 2008. SIAR: stable isotope analysis in R. The Comprehensive R Archive Network) Available at http://cran. r-project. org/web/packages/siar/index. html [Verified 15 July 2012]. 
Pasche N, Schmid M, Vazquez F, Schubert CJ, Wüest A, Kessler JD, Pack MA, Reeburgh WS, Bürgmann H. 2011. Methane sources and sinks in Lake Kivu. Journal of Geophysical Research: Biogeosciences 116(G3):G03006.

Perga M-E, Gerdeaux D. 2004. Changes in the $\delta^{13} \mathrm{C}$ of pelagic food webs: the influence of lake area and trophic status on the isotopic signature of whitefish (Coregonus lavaretus). Canadian Journal of Fisheries and Aquatic Sciences 61(8):1485-92.

Phillips DL, Inger R, Bearhop S, Jackson AL, Moore JW, Parnell AC, Semmens BX, Ward EJ. 2014. Best practices for use of stable isotope mixing models in food-web studies. Canadian Journal of Zoology 92(10):823-35.

Polsenaere P, Savoye N, Etcheber H, Canton M, Poirier D, Bouillon S, Abril G. 2013. Export and degassing of terrestrial carbon through watercourses draining a temperate podzolized catchment. Aquatic Sciences:1-21.

Rautio M, F Vincent W. 2007. Isotopic analysis of the sources of organic carbon for zooplankton in shallow subarctic and arctic waters. Ecography 30(1):77-87.

Rautio M, Mariash H, Forsström L. 2011. Seasonal shifts between autochthonous and allochthonous carbon contributions to zooplankton diets in a subarctic lake. Limnology and Oceanography 56(4):1513-24.

Raymond PA, McClelland J, Holmes R, Zhulidov A, Mull K, Peterson B, Striegl R, Aiken G, Gurtovaya T. 2007. Flux and age of dissolved organic carbon exported to the Arctic Ocean: A carbon isotopic study of the five largest arctic rivers. Global Biogeochemical Cycles 21(4).

Raymond PA, Hartmann J, Lauerwald R, Sobek S, McDonald C, Hoover M, Butman D, Striegl R, Mayorga E, Humborg C. 2013. Global carbon dioxide emissions from inland waters. Nature 503(7476):355-9.

Reimer PJ, Brown TA, Reimer RW. 2004. Discussion: reporting and calibration of postbomb ${ }^{14} \mathrm{C}$ data. Radiocarbon 46(3):1299-304.

Rosell R, Maguire C, McCarthy T. 1998. First reported settlement of zebra mussels Dreissena polymorpha in the Erne System, Co. Fermanagh, Northern Ireland. Biology and Environment: Proceedings of the Royal Irish Academy. Royal Irish Academy 191-3. 
Rosell R, Gibson C. 2000. Interlinked changes in fish populations and their environments in lower Lough Erne, Northern Ireland. Verhandlungen der Internationale Verein für Limnologie 27, 2095-9.

Rottberger J, Gruber A, Boenigk J, Kroth PG. 2013. Influence of nutrients and light on autotrophic, mixotrophic and heterotrophic freshwater chrysophytes. Aquatic microbial ecology 71(2):179-91.

Seifert LI, Scheu S. 2012. Linking aquatic and terrestrial food webs-Odonata in boreal systems. Freshwater Biology 57(7):1449-57.

Smyntek PM, Maberly SC, Grey J. 2012. Dissolved carbon dioxide concentration controls baseline stable carbon isotope signatures of a lake food web. Limnology and Oceanography 57(5):1292.

Stuiver M, Polach HA. 1977. Discussion; reporting of C-14 data. Radiocarbon 19(3):355-63.

Taipale S, Kankaala P, Jones RI. 2007. Contributions of Different Organic Carbon Sources to Daphnia in the Pelagic Foodweb of a Small Polyhumic Lake: Results from Mesocosm DI ${ }^{13} \mathrm{C}$ Additions. Ecosystems 10(5):757-72.

Taipale S, Kankaala P, Tiirola M, Jones RI. 2008. Whole-lake dissolved inorganic ${ }^{13} \mathrm{C}$ additions reveal seasonal shifts in zooplankton diet. Ecology 89(2):463-74.

Tittel J, Wiehle I, Wannicke N, Kampe H, Poerschmann J, Meier J, Kamjunke N. 2009. Utilisation of terrestrial carbon by osmotrophic algae. Aquatic Sciences-Research Across Boundaries 71(1):46-54.

Trumbore S, Vogel J, Southon J. 1989. AMS C-14 measurements of fractionated soil organic-matter-an approach to deciphering the soil carbon-cycle. Radiocarbon 31(3):644-54.

Trumbore S. 2009. Radiocarbon and soil carbon dynamics. Annual Review of Earth and Planetary Sciences 37:47-66.

Van der Plicht J, Hogg A. 2006. A note on reporting radiocarbon. Quaternary Geochronology 1(4):237-40.

Wilkinson GM, Pace ML, Cole JJ. 2013a. Terrestrial dominance of organic matter in north temperate lakes. Global Biogeochemical Cycles 27(1):43-51. 
Wilkinson GM, Carpenter SR, Cole JJ, Pace ML, Yang C. 2013b. Terrestrial support of

pelagic consumers: patterns and variability revealed by a multilake study. Freshwater Biology 58(10):2037-49.

Zhou Q, Gibson CE, Foy RH. 2000. Long-term changes of nitrogen and phosphorus loadings to a large lake in North-West Ireland. Water Research 34(3):922-6.

Zigah P, Minor E, Werne J, McCallister SL. 2012. An isotopic $\left({ }^{14} \mathrm{C}, \delta^{13} \mathrm{C}\right.$, and $\left.\delta^{15} \mathrm{~N}\right)$ investigation of the composition of particulate organic matter and zooplankton food sources in Lake Superior and across a size-gradient of aquatic systems. Biogeosciences 9:3663-78.

\section{FIGURE CAPTIONS:}

Figure 1: Lower Lough Erne, Fermanagh, Northern Ireland. Lake and river sites that were sampled are marked on the map. LE1, LE3 and LEP are pelagic sites, LEA1-LEC are littoral sites

Figure 2: Stable carbon and nitrogen isotope results from Lower Lough Erne fish species collected in 2010.

Figure 3a-c: Proportions of dietary sources contributing to the diets of perch (Perca fluviatilis, Figure 3a), pollan (Coreganus autumnalis, Figure 3b) and roach (Rutilis rutilis, Figure 3c). Mixing models were generated using Siar version 4.2, $R$ version 2.12 .1 and are described in more detail in the text. $A=$ littoral invertebrates. $B=$ chironomid. $C$ $=$ calanoid zooplankton. $\mathrm{D}=$ Daphnia. $\mathrm{E}=$ roach fry. $\mathrm{F}=$ perch fry. Shaded grey levels in plot refer to 5, 25, 75 and $95 \%$ confidence intervals.

Figure 4: $\Delta^{14}$ Cand stable carbon isotope measurements from Lower Lough Erne fish. Error bars represent the uncertainty on measurements. Horizontal lines denote the mean $\Delta^{14} \mathrm{C}$ as measured from calanoid zooplankton in winter and summer. Winter calanoid $\Delta^{14} \mathrm{C}$ results are analogous to those of modern terrestrial $\mathrm{C}$, summer to autochthous algal $\Delta^{14} \mathrm{C}$.

Figure 5: Stable isotope values of Lower Lough Erne pelagic invertebrate species. Points with error bars denote mean algal and POM isotope values with their associated standard deviations.

Figure 6: Invertebrate $\Delta^{14} \mathrm{C}$ and $\delta^{13} \mathrm{C}$ measured from selected Lower Lough Erne invertebrate species. Winter samples were collected in February and March, and summer samples in May and August 2011. Points with error bars denote mean algal and POM isotope values with their associated standard deviations. Mean DOC $\Delta^{14} \mathrm{C}$ (relatively consistent over the duration of the study) is shown as a horizontal line $-\delta^{13} \mathrm{C}$ values were unreliable for DOC samples. Dashed lines denote the error associated with the mean.

\section{TABLE CAPTIONS}

Table 1: Location data for sampling sites including depths of fish net placement. 